\title{
Evaluation of environmental degradation as an unprecedented threat to human security in Pakistan
}

\author{
Bilal Aslam*1-2 ${ }^{\text {Shabnam Gul }}{ }^{3} \mid$ Muhammad Faizan Asghar ${ }^{4}$
}

1. Centre for South Asian Studies, University of the Punjab, Lahore, Punjab, Pakistan.

2. Department of Community \& Environmental Sociology, University of Wisconsin Madison, USA.

3. Department of International Relations, Lahore College for Women University, Lahore, Pakistan.

4. School of Peace and Counter Terrorism Studies, Minhaj University, Lahore, Punjab, Pakistan.

*Correspondence Emails: bilalfsd@gmail.com | baslam@wisc.edu

\begin{abstract}
Environmental degradation over the years has gained much significance as a non-traditional security threat and it can be regarded as an emerging challenge to the human security in Pakistan as well. This paper attempts to establish a linkage between the environmental degradation and human security by analysing the various causes of the environmental degradation in Pakistan and exploring its impact on the various dimensions of the human security. The study incorporates the secondary data in the form of reports published by the World Bank, United Nations Environment Program, Ministry of Finance \& Ministry of Climate Change Pakistan and also the newspapers and online resources. The qualitative methodology has been used to analyse the data obtained through the secondary sources and test the hypothesis that environmental degradation is a new and unprecedented threat to the human security in Pakistan. This paper suggests that the sustainable development policies can help in dealing with is the issue of environmental degradation, which consequently will positively impact the human security in Pakistan. The study also paves the way for policy-oriented research in the field of sustainable development.
\end{abstract} Article History

Received:

March 3, 2021

Last Revised:

May 21, 2021

Accepted:

May 31, 2021

Published: June 3, 2021

Keywords: environment, environmental degradation, environmental management, climate change, human security, non-traditional security threats, sustainable development.

How to Cite: Aslam, B., Gul, S., \& Asghar, M. F. (2021). Evaluation of environmental degradation as an unprecedented threat to human security in Pakistan. Liberal Arts and Social Sciences International Journal (LASSIJ), 5(1), 197-211. https://doi.org/10.47264/idea.lassij/5.1.14

Publisher's Note: IDEA PUBLISHERS (IDEA Journals Group) stands neutral with regard to the jurisdictional claims in the published maps and the institutional affiliations.

Copyright: ( $) 2021$ The Author(s), published by IDEA PUBLISHERS (IDEA Journals Group). This is an Open Access article published under the Creative Commons Attribution-NonCommercial 4.0 International License (http://creativecommons.org/licenses/by-nc/4.0/) 


\section{Introduction}

Environmental degradation puts serious constraints on human development and economic wellbeing of the people of Pakistan. The economic cost of environmental degradation in 2016 was estimated at US\$ 25.1 billion (8.96 percent GDP equivalent) for air pollution, water pollution and soil contamination (World Bank, 2019). It may be argued that both natural and man-made factors contribute to the problem of environmental degradation in Pakistan. Rapid growth of population and industry, urbanization, poor management of available natural resources and lack of implementation of state policies are key contributions to the said problem. The issue of environmental degradation has severe consequences in terms of human security. Furthermore, it has increased the vulnerability of the marginalized communities that are dependent on the natural resources. The phenomenon that has been explained by Robert D. Kaplan in his Population and Environmental Scarcity Model which also serves as the theoretical foundation of this paper (Kaplan, 2014) in addition to the wider security agenda proposed by Buzan et al. (1998) that extends the scope of study from the resource scarcity to the sustainable development.

However, the earth also causes ecological issues by itself, and the environment is always on verge of change with or without human factor. Thus, both natural and man-made causes of the environmental degradation have been taken into consideration in this paper. These causes have been explored by using the document analysis technique of the qualitative methodology which has been incorporated in this paper. Furthermore, the document analysis has also been used to analyse the reports published by national and international organizations, research papers, books, and newspapers to evaluate the impact of the environmental degradation on human security in Pakistan. Bowen has stated that "analysing documents incorporates coding content into themes similar to how focus group or interview transcripts are analysed" (Bowen, 2009). The qualitative data analysis has been conducted on the basis of pre-determined theme of the literature while other themes emerged during the course of research have also been collaborated to form a definite result of the study.

The man-made causes of the environmental degradation in Pakistan include the increasing air pollution, water pollution and deforestation. Pakistan has also been a victim of the natural disasters and calamities like earthquakes, floods, droughts and more recently heatwaves. Following is the detailed account of the causes and consequences of the environmental degradation in Pakistan.

\section{The climate change}

Pakistan has been experiencing an adverse climate change. The region's projected temperature increase in the coming years is higher than the global average. On a national level, the trend of temperature time series indicates an increased warming in the country. The figure- 1 below shows the trends of the increase in temperature in Pakistan. Consequently, Pakistan is facing increased monsoon variability. The glaciers are recessing in the Hindu Kush-Himalayan $(\mathrm{HKH})$ region, which is a serious threat to the water flow of the Indus River System (IRS). The melting of the glaciers is also reducing the natural reservoirs' capacity. The water and heat stress is causing a decrease in the agricultural productivity. Siltation of dams in resulting in low reservoir capacity and over all climate change is creating a great risk of droughts and floods (see, Jan et al., 2020). 


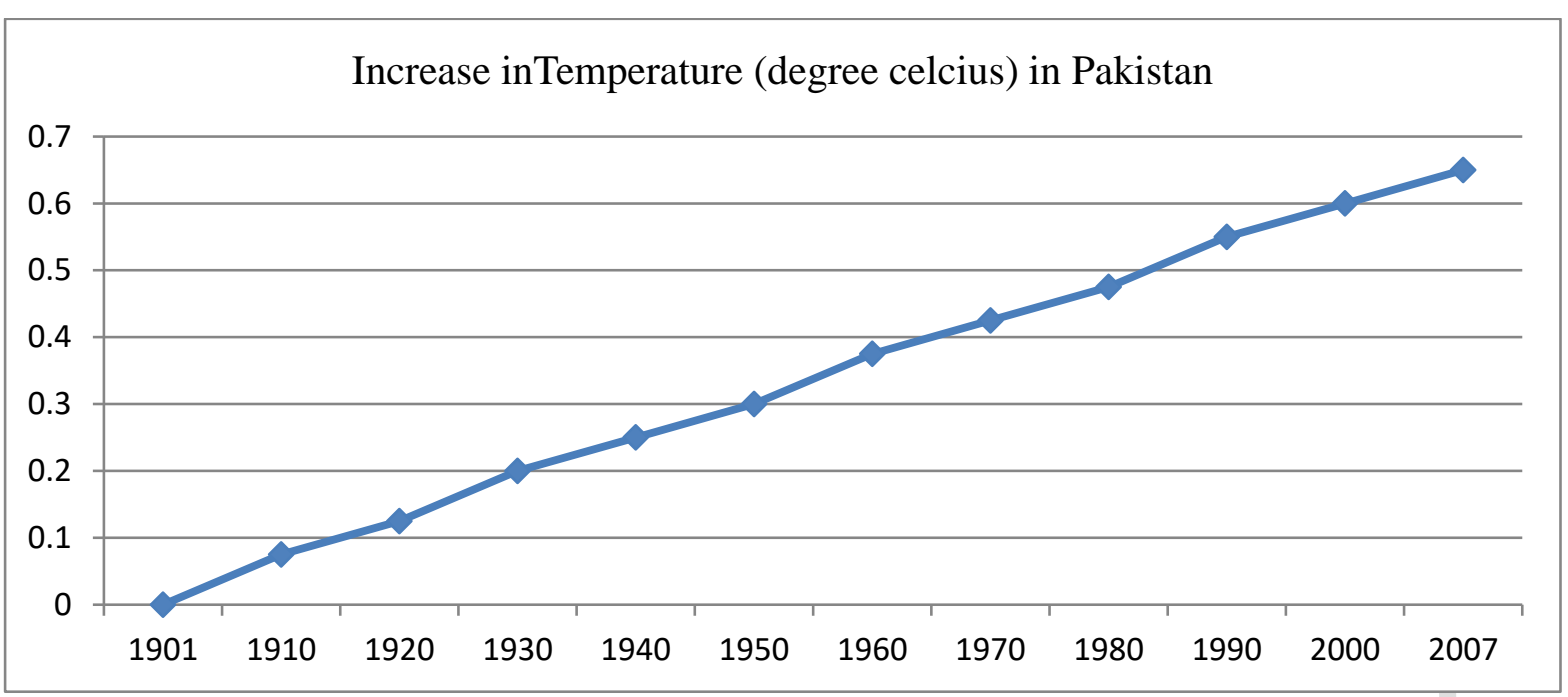

Figure 1: trend of increase in temperature (per decade) in Pakistan (Afzaal et al., 2009)

\subsection{Heat waves}

In the recent years, a severe heat-wave stuck Pakistan on 22 June 2015, where temperatures hit 45 degrees Celsius (111 Fahrenheit) in Karachi. As of 29 June, it had caused deaths of more than 2,000 people mostly in Karachi. The hospitals treated nearly 80,000 people for the effects of heatstroke and dehydration during the last week of June 2015, according to medical officials. (Mansoor, 2015). Dr Mohsin Iqbal in the report of Intergovernmental Panel on Climate Change (IPCC) pointed out that the rise in temperature in Pakistan is higher than the average global rise in temperature. He explained that "There has also been an increase in climate induced extreme events - an increase in heat waves, droughts, floods, cyclones and wildfires. In Pakistan, the frequency and intensity of extreme events has increased; there were super floods in 2010 and 2011 and back-to-back floods in 2011, 2012, 2013 and 2014. There have been droughts, intense heat waves and severe cyclonic storms in the country." (IPCC, 2014).

\subsection{Floods}

The flood of 2010 killed 1,700 people and affected 20 million people approximately. It also caused huge damage to housing, infrastructure, agriculture and livestock, which resulted into loss of billions of dollars (Economic Survey of Pakistan, 2010-11). The heavy rainfall across the Sindh province in September 2011 resulted into a devastating flood affecting 5.3 million people and destroying 1.2 million homes in 23 districts across the province. 361 deaths were reported because of drowning and outbreak of diseases. The flood also affected 1.7 million acres of arable land and millions of cattle were displaced. (Rana \& Ali 2011).

In September 2012, the flood killed more than 100 people, destroyed thousands of acres of land in KPK, Southern Punjab and Northern Sindh. (Dawn, 2012). Similarly, the flood of August 2013 took more than 40 lives. In September 2014, River Chenab and River Jhelum were inundated due to heavy rainfall in IHK \& AJK region affecting 4,000 villages and leaving 700,000 people homeless. This flood also took 367 lives and damaged livelihoods of the people of AJK, GB and Punjab particularly. More than 2.4 million acres of arable land was flooded, and more than 9,000 cattle perished (Davies, 2014). 
In 2015, the heavy monsoon rains and floods in various parts of Pakistan killed 169 people till $5^{\text {th }}$ of August and injured 126 people. (Floods kill 169 people, 2015). However, the death toll continues to increase as the high floods in Indus River have affected 917,719 people according to a report by NDMA (Monsoon Weather Situation, 2015).

The flood has caused damage to all four provinces and to GB and AJK regions as well, but the KPK province has suffered the most where Chitral is the worst hit region. 3,320 houses have been damaged in KPK province and 79 people have lost their lives so far. The death toll in Punjab has also reached 48 and in Balochistan 13 deaths have been reported so far. The GB and AJK regions have 7 and 22 reported deaths respectively.

Table-1: Preliminary collected data by NDMA of the national losses due to floods of 2015

\begin{tabular}{|l|l|l|l|l|l|l|}
\hline $\begin{array}{l}\text { Sr. } \\
\text { No. }\end{array}$ & Provinces & Deaths & Injured & $\begin{array}{l}\text { Houses } \\
\text { Damaged }\end{array}$ & $\begin{array}{l}\text { Villages } \\
\text { Affected }\end{array}$ & Population Affected \\
\hline 1 & Balochistan & 13 & 33 & 798 & Being Accessed & 69,976 \\
\hline 2 & KPK & 79 & 70 & 3320 & Being Accessed & Being Accessed \\
\hline 3 & Punjab & 48 & 13 & 2025 & 496 & 463,902 \\
\hline 4 & Sindh & - & - & - & 2097 & $1,001,969$ \\
\hline 5 & AJK & 22 & 5 & 237 & 17 & - \\
\hline 6 & GB & 7 & 6 & 812 & 286 & 35,717 \\
\hline \multicolumn{2}{|l}{ Total } & 169 & 126 & 5,795 & 2,493 & $1,572,191$ \\
\hline
\end{tabular}

Sources: National Losses/Damages due to Floods in 2015 (NDMA, 2015)

\section{Water pollution}

Water pollution has become one of the most significant concerns in Pakistan. The untreated sewage water of the big cities, industrial chemical waste and surplus agricultural drainage contributes to contamination of the water resources like rivers, lakes and the underwater reserves. The causes of the water deterioration in Pakistan are as follows:

\subsection{Industrial waste}

The industrial growth and urbanization are among those factors which have contributed much to the issue of water pollution in Pakistan. The big cities and urban centres dispose of the sewage into the waterways that threatens the human health and the animal health. In Pakistan about two million tons of the human waste is accumulated in urban areas each year and almost half of it gets into the waterways and pollutes them (Raza, 2009). The discharge of industrial waste in form of toxic chemicals, radioactive materials and other solids and liquids is also deteriorating the quality of water adjacent to the industrial areas of Punjab, Sindh and KPK provinces. In Karachi alone there are more than six thousand industrial units which discharge their waste containing heavy metals, poisonous chemicals, toxic solids and liquids directly to the water system that leads to the sea. This untreated waste has affected the marine environment, harmed the flora and fauna (WWF, 2010) and has altered the physio-chemical parameters of composition of soil and vegetation beyond maximum safe limits set by WHO. Similarly, a study conducted in Faisalabad also showed that the irrigation water when mixed with industrial effluent contaminated soil and plants with toxic metals. The soil extracts were found to have concentrations of heavy metals indicating that effluents also pollute vegetation. (Saif et al., 2005). 
In Punjab, there are over one thousand industrial units across the province mainly concentrated in the districts of Lahore, Faisalabad, Gujranwala, Sialkot, Sheikupura and Kasur. These units discharge five thousand cusecs of toxic effluents into the water. On the other hand, there are over a hundred points where the sewage water is being directly fed to the drains and canals across the province. This wastewater eventually flows to rivers and also contaminates the groundwater. The groundwater samples collected from the surroundings of these industrial areas also indicated the presence of high level of trace metals thus making it unsuitable for drinking purposes (Zia et al., 2005). The textile industry is the largest manufacturing industry in Pakistan and contributes roughly $10 \%$ of the GDP (Statistics on Textile, 2013). The textile processing requires large quantity of water for dyeing, bleaching, and printing of fabric. The wastewater generated in this processing has serious implications. The chemical processing involves almost $70 \%$ of the total industrial pollution.

\subsection{Agricultural activities}

Agricultural activities which involve the use of fertilizers and pesticides for the production of crops also deteriorate the quality of water. In Pakistan the annual use of fertilizers is 5.6 million tons, and the use of pesticides is estimated to be 70,000 tons per annum (World Bank 2016). The consumption of fertilizers in Pakistan is also increasing and these fertilizers pollute the groundwater and the surface water, which then goes to the lakes and rivers and contaminates them too. This has been highlighted in various studies including the investigative report by Pakistan Council of Research in Water Resources (PCRWR), which collected and tested a few samples of the water from the agricultural runoff and found out that one-fifth of the samples had the traces of the residues of fertilizers and pesticides. The report identified that the chemical contamination due to fertilizers and pesticides in the water system of Punjab is way beyond the WHO's safety limits (Kahlown et al., 2015).

\subsubsection{Impact of water pollution on human security}

Water pollution of the surface and ground water resources has had a negative impact on the human security in Pakistan. The domestic, industrial and the agricultural activities have deteriorated the quality of water and have raised serious health related issues. The water pollution also contributes significantly in damaging the livelihoods of thousands of farmers. It also affects the food security and productivity. This polluted water when seep into the soil causes salinity and water-logging issues. Almost $13 \%$ of the cultivated area of Pakistan has been affected by salinity and water- logging. The irrigation water containing high levels of contamination also causes top-soil damage. The cost of cropping on the saline land in Pakistan is estimated to be PKR 55 billion per annum (World Bank, 2016).

A study conducted by WWF Pakistan on situation analysis of the water resources of Lahore shows that Lahore is in a constant danger because of the huge discharge of the untreated industrial waste. The River Ravi has become the most polluted river in Punjab province. This polluted water causes serious health related issues like the intestinal worms, bladder cancer, diarrhoea, bone deformation, cholera, hepatitis, stomach illnesses, typhoid and many skin problems. The presence of the toxic substances in irrigation water also causes serious damage to animal life and the loss of fishery. The contaminated surface water of the River Ravi for the use of irrigation and other purposes has serious consequences on human health. The farmers are using the sewage water for the production of vegetables and fruits in the periphery of Lahore, and these are prone to the heavy metal contamination and can cause serious water- 
related diseases (WWF, 2014). A study conducted by UNICEF estimated the total health cost of the water-related mortality and morbidity to be PKR 114 billion.

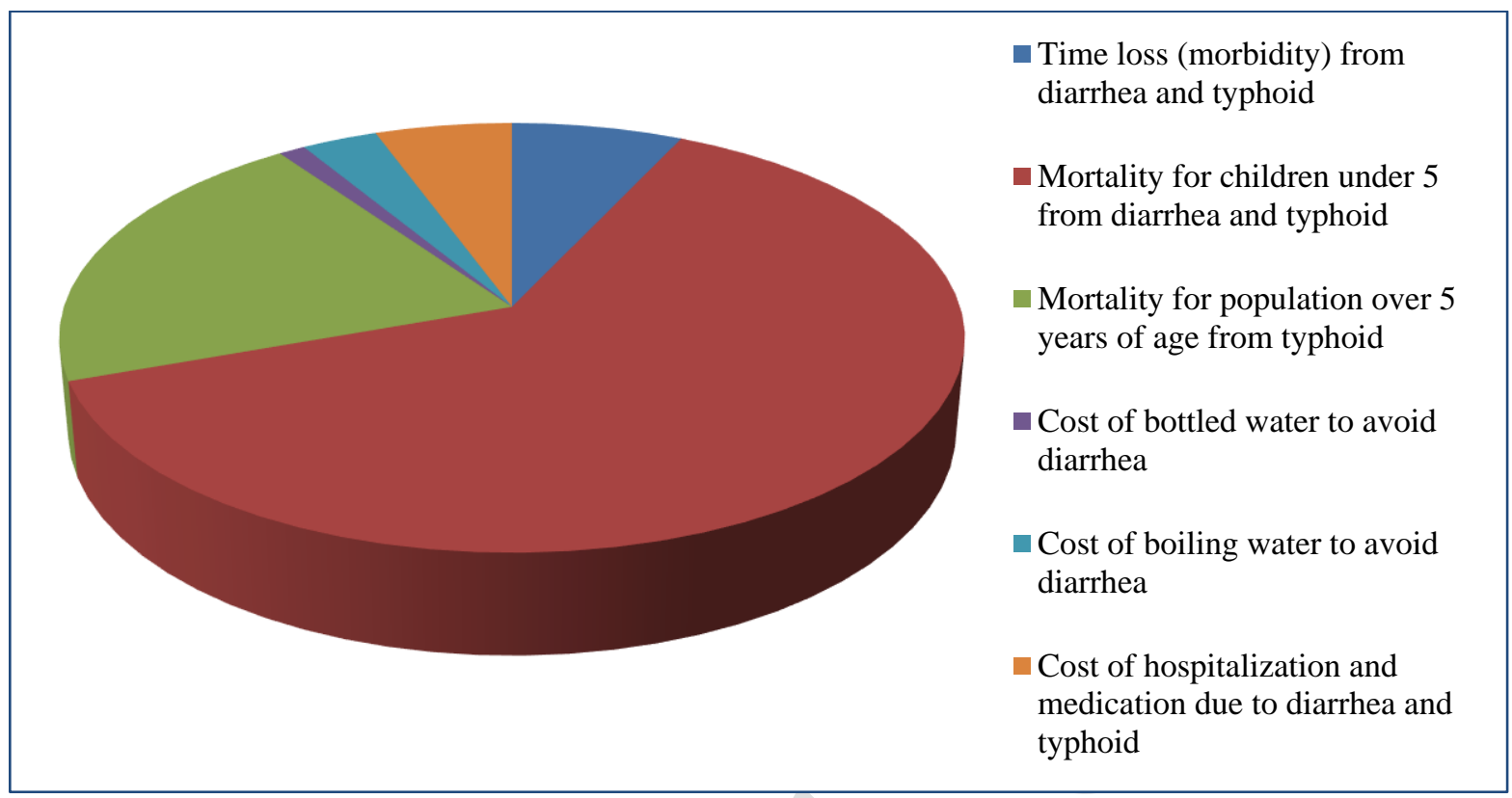

Figure 2: Health cost of the water-related mortality and morbidity (UNICEF, 2014)

The fishing industry has also suffered a lot because of the water pollution. The growth of fisheries has seen a steady decline over the period of time. The effluent from the industries such as leather and textile destroy the aquatic life drastically (Compendium on Environment, 2010). The water pollution also affects the biodiversity and the coastal eco-systems in Pakistan. The coastal eco-systems are dependent on mangroves, which provide the habitat to fish, birds and reptiles. The waterfowl of South Asia also find shelter in these mangroves all along their migratory trail. The water pollution because of the industrial effluent and other activities like port transportation and accidental oil spills from the ships etc. have contributed in shrinking these mangroves and threatened the lives of several species.

\section{Air pollution}

In the last two decades, there has been exponential increase in the emissions of the green-house gases. Consequently, the air pollution has become one of the most important environmental concerns in Pakistan. Previously, it was considered to be an urban problem, but the situation has changed over the period of time and the rural areas also face the challenges posed by the air pollution especially in the form of Indoor Air Pollution (IAP). Rapid increase of population, urbanization and the industrial growth has exacerbated the situation further. The industrial emissions, combustion of the municipal waste, emissions from the vehicles, burning of the biomass and fossil fuels contribute to the air pollution in Pakistan. Following is a detailed account on these major factors of air pollution and their impacts on the human security of the people of Pakistan. The shift of rural population to urban areas for better living conditions and employment opportunities is resulting into the urbanization in Pakistan and this phenomenon is also aggravating the issue of air pollution.

A study conducted by SUPARCO in the large cities of Pakistan identified that the level of fine particulate matter has exceeded in almost all of those cities by excepted standards. These cities 
included Karachi, Lahore, Islamabad, Peshawar, Rawalpindi and Quetta. The highest levels were recorded in Lahore and Quetta. Another study conducted by Pakistan Environmental Protection Agency in collaboration with the Japan International Cooperation Agency (JICA) in cities of Punjab province including Lahore, Faisalabad, Rawalpindi and Gujranwala concluded that the fine PM level in these cities was 6 to 7 times more than the WHO accepted standards (Aziz, 2006).

Table-2: Air pollutant concentrations based on hourly averages in various cites of Pakistan

\begin{tabular}{|l|l|l|}
\hline Pollutant & Averaging Time & Concentration Range $\left(\mu \mathrm{g} / \mathrm{m}^{3}\right)$ \\
\hline Carbon monoxide & $8 \mathrm{~h}$ & $160-4300$ \\
\hline Ozone & $1 \mathrm{~h}$ & $9.2-78$ \\
\hline Oxides of nitrogen & $24 \mathrm{~h}$ & $3.8-109$ \\
\hline Sulfur dioxide & $24 \mathrm{~h}$ & $2-23$ \\
\hline Lead & $24 \mathrm{~h}$ & $0.06-21.5$ \\
\hline Total suspended particulate matter & $24 \mathrm{~h}$ & $180-1375$ \\
\hline Particulate matter $<10 \mu \mathrm{m}$ diameter & $24 \mathrm{~h}$ & $85-835$ \\
\hline
\end{tabular}

Source: Pollutant concentrations in different cities of Pakistan (Aziz, 2006)

Various factors contribute to degradation of the air quality including the vehicular emissions which constitute 60-70\% of the total urban air pollution in Pakistan according to some experts (Aziz, 2006). The total number of the registered vehicles in Pakistan during 1992 was 3.179 million, which had doubled in 2010 as the number of registered vehicles reached 6.757 million. The vehicular emission of hydrocarbons, sulphur dioxide, carbon monoxide, aldehydes and nitrogen oxides are dangerous pollutants to human health, causing diseases like chronic bronchitis, irritation and asthma. The combustion of the solid waste also deteriorates the quality of air. The amount of the solid waste generated daily is estimated to be 54,888 tons. Unfortunately, there exists no proper solid waste management system in Pakistan. It is dumped in open spaces and usually burnt at low temperatures which liberate highly toxic compounds and other pollutants that are extremely harmful for the air quality. Industrial activities that involve the combustion of the fossil fuels, use of furnace oil, and the industrial processes that include production of fertilizers, pesticides, sugar etc. have intensified the issue of the air pollution in Pakistan.

According to a study by Sial et al. there were 6634 registered industrial units in Pakistan, out of which 1228 were considered to be highly polluting (Sial et al., 2006). The large industrial units like power plants, steel mills, textile processing mills etc. generate pollutants, which degrade the quality of air in surrounding areas. Small industrial units like brick kilns, molding and recycling plants for steel and plastic etc. also impact the quality of surrounding air by generating dense black smoke called "soot". These units use the waste fuels like low grade coal, wood, old tires, textile waste that produces the toxic substances, particulate matter, carbon monoxide, sulphur oxide and the nitrogen oxide (World Bank, 2016). Another worrying issue is that there exist no distinguished industrial zones in the country and the residential areas are diffused into the industrial zones. The expansion of the cities has resulted into inclusion of the industrial units to the municipal limits. Therefore, the industrial estate, which previously used to be on the periphery of the cities now stands side by side with the residential and commercial areas. For instance, there are about 450 brick kilns, which surround the Peshawar city. These kilns use cheap fuels like used mobil oil, old tires and textile waste that generate extremely harmful particulate matter. 


\subsection{Smog and winter-fog}

Smog is caused due to the vehicular emissions and the emissions from burning of coal and furnace oil. This generates the pollutants like carbon monoxide, sulphur dioxide and nitrogen oxide. This matter has the capacity to travel over hundreds of thousands of kilometres. The winter fog in Pakistan is considered to be the result of this trans-boundary air pollution that originates from India and China. A study conducted by SUPARCO (2016) endorsed this assertion as it indicated that the sulphur dioxide traces had travelled to Lahore through the air parcels that originated some $580 \mathrm{~km}$ away to south. The data from the remote sensing satellites Meteosat, NOAA and Modis showed that the fog extended over 1,500 Kms to north-eastern India and possibly caused due to excessive burning of coal and other fossil fuels in India.

\subsection{Indoor Air Pollution (IAP)}

Air pollution because of burning of fossil fuels and other non-commercial biomass fuels like wood, crop residue and animal dung have severe health implications. The majority of rural population of Pakistan (86\%) and a fair proportion of the urban population (32\%) rely on these fuels for household heating purposes. The combustion of these fuels produces a lot of particulate matter and toxic substances which leads to high levels of the IAP in Pakistan. Indoor air pollution has serious health hazards especially for the children and women. It also causes serious diseases in adults like chronic bronchitis, cataract and the lung cancer. A study estimated that IAP in Pakistan has caused an annual 28,000 or more deaths and an economic cost of PKR 60-74 billion was estimated (World Bank, 2016).

\subsubsection{Impact of air pollution on the human security}

Air Pollution poses serious threats on the human security in Pakistan. It undermines the health and causes various diseases. For instance, the particulate matter aggravates the respiratory and cardiovascular diseases. An investigative study was conducted on 1000 policemen in 2002, to find out the impact of air pollution on the health of traffic policemen. The results were shocking as $80 \%$ of these policemen were found to be infected with chronic obstructive pulmonary diseases and eye-nose-throat problems. Around $40 \%$ were found to have lung problems. A few had even developed tuberculosis and asthma. A study conducted by World Bank on the impact of particulate matter on health in Pakistan showed that it caused deaths of more than 22,000 people annually including 700 children. The economic loss in terms of the health cost was estimated to be PKR 65 billion. Table 3 shows the breakdown of these costs.

Table-3: Annual health impact of air pollution

\begin{tabular}{|l|c|c|}
\hline Description & Attributed total cases & Annual Costs (PKR billion) \\
\hline Premature mortality adults & 21,791 & $58-61$ \\
\hline Mortality children under 5 & 658 & 0.83 \\
\hline Chronic bronchitis & 7,825 & 0.06 \\
\hline Hospital admissions & 81,312 & 0.28 \\
\hline Outpatient hospital visits & $1,595,080$ & 0.80 \\
\hline Restricted activity days & $81,541,893$ & 2.06 \\
\hline Lower respiratory illness in children & $4,924,148$ & 0.84 \\
\hline Respiratory symptoms & $706,808,732$ & 0.00 \\
\hline Total & \multicolumn{2}{|c|}{} \\
\hline
\end{tabular}

Source: Annual health impact of air pollution (World Bank, 2016). 
IAP also adds up to the health cost and is estimated to be PKR 55-70 billion. Air pollution also causes the acid rain because of the emissions of oxides of sulphur and nitrogen. It has severe health implications for the human beings and is harmful for the plants and marine life as well. Air pollution also causes significant damage to the agricultural production. A study conducted on the suburbs of Lahore found out that the air pollution has reduced the quantity of production of wheat and rice (Maggs et al., 2005). This is an alarming situation for Pakistan as with the growing population, the demand for agricultural products is continuously increasing and to meet these demands, the air pollution needs to be controlled.

\section{Deforestation}

In Pakistan, forest cover is just around five percent of the total area and is on continuous decline. According to a report published by UNDP, the estimated annual decline of forest is 0.2 percent to 0.5 percent. The forest cover has reduced from 3.59 million hectares to 3.32 million hectares with an average rate of reduction of 27,000 hectares annually (UNDP, 2010). This is quiet an alarming situation as if this continues at the same rate all forest area of Pakistan will be consumed within 12-15 years. Forests in Pakistan are source of fuel wood particularly for the low-income groups and it constitutes 32 percent of the total energy needs. The demand of forest wood in the form of fuel wood and timber for construction continues to increase with the increase in population. The wood consumption in 1993 was 30 million cubic meters and is projected to reach 50 million cubic meters by 2020 (FAO, 2020). Deforestation in Pakistan has contributed to land erosion, landslides and also increased the frequency of floods. In addition to this, the forest loss also results into the loss of the biodiversity and the natural habitat. Around 6.4 million hectares of area covered by forests provides sustenance to the livestock. The phenomenon of deforestation in Pakistan has aggravated in the last two decades and caused huge economic loss to the country. The estimated cost of the deforestation in Pakistan is 206 to 334 million PKR according to the report by World Bank.

Table-4: The annual cost estimation of deforestation in Pakistan.

\begin{tabular}{|l|l|l|l|}
\hline & Annual Cost \\
\hline & Low estimate & Mean & High Estimate \\
\hline Direct Use & 122 & 186 & 250 \\
\hline Sustainable timber & 28 & 71 & 114 \\
\hline Fuel wood & 41 & 41 & 41 \\
\hline Non timber products & 25 & 25 & 25 \\
\hline Tourism and recreation & 28 & 49 & 70 \\
\hline Indirect Use & 84 & 84 & 84 \\
\hline Direct + Indirect & 206 & 270 & 334 \\
\hline
\end{tabular}

Source: Annual cost estimation (in PKR millions) of deforestation in Pakistan (World Bank, 2016)

The most significant factor is the mismanagement at the governmental level and the negligence of the severity of the issue. The illegal logging activities by the timber mafia have also worsened the problem. Some other factors have been discussed below:

- The increasing demand of the wood for construction, furniture and other commercial products like paper etc.

- Development of infrastructure like roads, buildings and water reservoirs.

- The dependence on wood for the fuel for domestic and commercial purposes. 
- Over-gazing by the expanding livestock and cattle.

- Natural factors like forest fires, floods, and storms.

- Pests and plant diseases reducing the growth of trees.

- Remote locations make it difficult to monitor the forests.

The wars and conflicts have severe environmental implications and the impact of war on the forestation and biodiversity cannot be overlooked. The mountain ecosystem of the Himalayan Mountain range, in the western part of Pakistan has been prone to the conflicts and wars. The terrain adjacent to the Durand-line that serves as the border between Pakistan and Afghanistan is one of the most rugged and tough terrain of the world. The history of conflicts in Afghanistan and the invasion by ISAF forces after $9 / 11$ has contributed much to disrupting the natural ecosystem in that region. Similarly, the South Wazirstan region in the northern part of the country has also turned into a rugged landscape because of the ongoing military operation Zrb-eAzab.The air strikes, bombings and the ground fighting has disturbed the wildlife and adversely affected many species including the migratory birds that travel from the northern Russia to this region. The military actions also result into internal displacement of the people, and they are forced to live in challenging conditions as refugees. These refuges chop down trees for making temporary shelters for themselves and this eventually leads to further aggravation of the environmental degradation.

\subsection{The impact of deforestation on human security}

Deforestation increases the frequency of the natural disasters. The diminishing forests on the sloping hills cause disruption of the absorption capacity of the water and make the downstream areas more vulnerable to the floods and land sliding. The watersheds of the river Kunar and the river Kabul eventually led to floods in districts of Charsadda and Nowshera in 2005 (WWF, 2005). The deforested land when exposed to sun becomes hard, dry and infertile. The rainfall also washes away the important nutrients and the topsoil resulting into loss of productivity. Deforestation in Pakistan also impacts the human health and agricultural productivity. The climate experts maintain that the diminishing forests have caused expansion in country's heat zone and contraction of the Indus delta. The unsustainable harvesting of the forests deteriorates the quality of life. The human security of the population that is dependent on the forest products for their livelihoods is more threatened. Moreover, the forest lands are huge attraction for the tourism industry. This industry provides direct or indirect employment to thousands of people in the northern areas, parts of Punjab province (like Muree) and the KP province. Deforestation makes these areas less attractive for the visitors and causes damage to the tourism industry. Consequently, it affects the people dependent on this industry for their livelihoods.

\section{Land degradation}

In Pakistan, the issue of irrigated land degradation is also increasing. The basic factors contributing to this problem are water logging, salinity and loss of fertility. The table 5 shows the comparison of the economic cost of various forms of the land degradation in Pakistan. The effect of salinity and water logging is estimated to impact the 40 percent of the total irrigated land. Salinity has turned out to be one of the most serious problems related to land degradation of Pakistan. This is because it has caused around 1.4 million hectares of the land uncultivable. The economic effects of salinity are also grave as it reduces the agricultural production and yield. The average estimated economic cost of salinity is PKR 55 billion or $0.9 \%$ of GDP 
(World Bank, 2016). In addition, the inability to expand the cultivation of land coupled with the increasing pressure of rapidly growing population has put serious constraints on the available irrigated land resources.

Table-5: Comparison of the economic cost of various forms of the land degradation in Pakistan

\begin{tabular}{|l|l|l|l|}
\hline & Low & Mean & High \\
\hline Salinity Costs & 30 & 55 & 80 \\
\hline Soil Erosion & 15 & 15 & 15 \\
\hline Rangeland Degradation & 3.6 & 4.2 & 5.4 \\
\hline Total Loss & 48.6 & 74.2 & 100.4 \\
\hline
\end{tabular}

Source: The economic costs (PKR billions) of various forms of land degradation (World Bank 2016)

\section{Impact of environmental degradation on sustainable development}

Sustainable development is a phenomenon that evolved strongly in Stockholm Conference on the Human Environment 1972, World Conservation Strategy 1980 and further evaluated in the international conservation movement. The articulation of this strategic report was supported in the 1992 United Nations Conference on Environment and Development held in Rio de Janeiro. Subsequently, in a decade these ideas were fostered by social activists around the world under the title of 'Local Agenda 21' and matured at the World Summit on Sustainable Development in Johannesburg 2002. Sustainability endows 'space' to engage in and address the challenges among societies, economies and natural environment, prevailing through time. The Brundt land Commission believed that sustainability is the capacity of humanity "... to ensure that it meets the needs of the present without compromising the ability of future generations to meet their own needs." The question 'what is to be sustained?' is usually answered in different perspective with variety of views.

The 'life support system' is what actually needs to be considered most important while discussing sustainability. Maintaining a healthy environment and ensuring quality of life by sustaining natural resources must be the focal point of sustainable development strategies. From an anthropocentric perspective, the dire need is the protection of 'ecosystem', which in turn provides environmental services to mankind such as water purification. A less anthropocentric approach views nature as an entity in itself whose value and sanctity has to be sustained. More revamped views suggest that all species on earth share equal rights of existence and sustenance entitling them as 'natural rights'. Whereas the discourse over 'What is to be developed?' gives prior weightage to economy. Development in production yields employment opportunities, while wealth elevates chances of investment and hence further increase in production. Development on institutional and organizational level is also prioritized in many debates. This emphasizes on development of governing body through policy formation and strategic pursuit. Another perspective of the developmental approach is human-centred development. It focuses on improvement of the quality of life, maximizing life expectancy, increasing literacy rate, political empowerment, equity in resource distribution, and ensuring healthy environment.

\subsection{Sustainable development in Pakistan}

Over the time, Pakistan has faced a lot of economic, social and environmental challenges emerging due to issues such as urbanization, industrialization, and deforestation and population 
growth. The resource base of the country is continuously being affected, and gradual increase in environmental degeneration is further obstructing the sustainability of development. Pakistan faces environmental issues such as lack of clean water resources, population growth and inadequate measures to sustain of renewable resources. Thus, it may be established that sustainable development is inversely proportional to the environmental degradation in Pakistan. An increase in the environmental degradation results in decreasing the sustainability, whereas lessening the environmental issues will result in more sustainability of a country's economy (see, Fatima et al., 2020). This study shows that human development in Pakistan is influenced by the environmental factors, including population growth, impoverishment, urbanization and economic growth that generate long-term influences on it. Moreover, the study evaluates the sustainability of economic development in Pakistan and its various environmental determinants.

\subsection{Impact of sustainable development on human security}

The interdependency of nature and society is unquestionable. This empirical finding has helped systems to map out policies and strategies that have proved to be more result oriented. This interdependency not only triggers threats from one side to another but also prompts mutual benefits. Researchers must not only consider the menacing outcomes of environmental degeneration or societal disintegration on each other but must also focus upon the potential of mutual improvement. Environmental issues have been threatening human security at various scales of time and space. As most of the time the threats arise at regional spatial scale and decadal time scale, so does these scales hold a chance for initiating welfare activities. Different communities and masses at large must be given chance to voice their needs and participate in articulation of decision about their security and development. People empowerment could be helpful in figuring out insecurities and hence dealing with appropriately. Finally, another stronger approach views nature as an entity in itself whose value has to be sustained for its own sanctity along with considering its essentiality for human beings. The broader idea of integration suggests that all species on earth share rights of existence and sustenance entitling them as 'natural rights', in addition to the greater emphasis on 'human rights' and the eventual need of sustaining security.

\section{Conclusion}

The environmental degradation through the degeneration of natural resources including forests, fisheries, and water coexisting with water and air pollution is a major hurdle in economic and human development. Chemical and organic waste produced by an ever-growing number of industries has been a reason for soil erosion and biodiversity loss. The environmental degradation in Pakistan is a serious issue that has severe implications in terms of the economic loss and the loss of biodiversity and natural habitat. There are both natural and man-made causes of the issue of environmental degradation in Pakistan. The natural causes include the climate change, heat waves and floods while the man-made causes mainly include water pollution, air pollution, deforestation and the land degradation. The issue of environmental degradation in Pakistan is raising serious equity concerns in the country. The future generations will have to face the consequences of what is being done today. The need of the hour is to device an effective system to tackle the issues we are facing and include the support from individuals, communities and social societies on multiple levels. Environmental degradation also affects the quality of life of human beings and puts constraints on the water security, food security and the heath security. 


\subsection{Recommendations}

The government should step up to face the challenges of environmental insecurities and energy scarcity, highlight appropriate responses and focus on climate protection. Development policies need to be developed for disaster reduction and preparedness, capacity building, crisis and conflict prevention, institutional strengthening, and raising awareness. It is very crucial to take scientific input into account, using the methods of problem recognition and anticipatory learning. The sustainable development policies can help in dealing with environmental degradation. The rapid increase in population also conveys unfavourable impacts on environment as it causes scarcity of resources and increase in pollution.

In order to ensure sustainability of the development in Pakistan we must undertake serious efforts to eradicate water pollution, ensure environmental protection, eliminate poverty, control population growth, acquire resource globalization and manage rate of urbanization whereas, an uncontrolled impoverishment and unchecked degradation of the environment may work as a catalyst, deriving adverse effects on the sustainable development in the country. Furthermore, introducing the green technologies can be an effective step to protect the environment while keeping the human development intact through industrialization, urbanization and liberalization of trade.

It is thus the need of the hour to elevate the quality of human resource development in Pakistan. The is required to eliminate poverty and boost awareness about preserving environment and safeguarding natural resources in order to attain and maintain sustainability of the development in the country. The human security in Pakistan is directly dependent on the environment and thus, to enhance the human security, the issue of environmental degradation needs to be dealt with seriously.

\section{References}

Afzaal, M., Haroon, M. A., \& Zaman, Q. (2009). Interdecadal oscillations and the warming trend in the area-weighted annual mean temperature of Pakistan. Pakistan Journal of Meteorology, 6(11), 13-19. https://www.semanticscholar.org/paper/InterdecadalOscillations-and-the-Warming-Trend-in-AfzaalHaroon/5b4a3954a72342d2fe77121b7211cac9306ac0b5

Aziz, J. A. (2006). Towards establishing air quality guidelines for Pakistan. EMHJ-Eastern Mediterranean Health Journal, $12(6), \quad 886-893$. https://apps.who.int/iris/handle/10665/117167

Aziz, J. A. (2006). Towards establishing air quality guidelines for Pakistan. EMHJ-Eastern Mediterranean Health Journal, 12(6), 886-893. https://apps.who.int/iris/handle/10665/117167

Bowen, G. A. (2009). Document analysis as a qualitative research method. Qualitative research Journal, 9(2), 27-40. https://doi.org/10.3316/QRJ0902027

Buzan, B., Wæver, O., Wæver, O., \& De Wilde, J. (1998). Security: A new framework for analysis. Lynne Rienner.

Davies, R. (2014, October 13), Pakistan floods, September 2014 - facts and figures. Flood List. http://floodlist.com/asia/pakistan-floods-september-2014-facts-figures 
Dawn (2012, September 10). Floods triggered by downpour wreak widespread devastation. http://www.dawn.com/news/748476/floods-triggered-by-downpour-wreakwidespread-devastation.

Economic Survey of Pakistan. (2011). Pakistan: Flood impact assessment 2010-11. http://www.finance.gov.pk/survey/chapter_11/Special\%20Section_2.pdf

FAO. (2020). 2019 Forestry sector review: Islamabad, Pakistan. https://doi.org/10.4060/ca4869en

Fatima, N, Ashraf, I., \& Zehraa, S. (2020). Sustainable consumption and production: An analysis of implementation of Pakistan's policy framework of SDG-12. Liberal Arts and Social Sciences International Journal (LASSIJ), 4(1), 114-129. https://doi.org/10.47264/lassij.4.1.11

Government of Punjab. (2007) Surface water quality monitoring plan (Revised), Lahore: Irrigation \& Power Department, Directorate of Land Reclamation Punjab, Pakistan.

Jan, A., Khan, T. A., \& Mahsud, M. I. (2020). The climate change awareness and literacy in Pakistan: Role of media and social actors. Liberal Arts and Social Sciences International Journal (LASSIJ), 4(2), 256-266. https://doi.org/10.47264/lassij.4.2.20

Kahlown, M.A, Chang, M.H, Ashraf, M., Hassan, M.S. (2003). Salt affected soils and their reclamation: Research report-4 2003. Pakistan Council of Research in Water Resources, Islamabad, Pakistan.

Kaplan, R. D. (2014). The coming anarchy (pp. 195-202). Routledge.

Maggs, R., Wahid, A., Shamsi, S. R. A., \& Ashmore, M. R. (1995). Effects of ambient air pollution on wheat and rice yield in Pakistan. Water, Air, and Soil Pollution, 85(3), 1311-1316. https://link.springer.com/article/10.1007/BF00477163

Mansoor, H. (2015, June 27). Fresh deaths, unclaimed bodies raise heatwave toll. DAWN News. http://www.dawn.com/news/1190705/fresh-deaths-unclaimed-bodies-raiseheatwave-toll?preview

Monsoon Weather Situation Report 2015. (2015, August 5). NDMA http://www.ndma.gov.pk/new/Documents/NDMA_Monsoon_Daily_Sitrep_No_23 5th_august_2015.pdf

NDMA. (2015, August 5). Floods kill 169 people across Pakistan. The Express Tribune, http://tribune.com.pk/story/932766/floods-kills-169-people-across-pakistan-ndma/

Rana, S., \& Ali, Z. (2011, September 13). Sindh rains: Govt scrambles as UN prepares to launch aid appeal. The Express Tribune. http://tribune.com.pk/story/251425/floodsworsen-270-killed-officials/

Raza, A. (2009, February 25). Six districts throwing untreated waste into Chenab. The News, http://www.thenews.com.pk/TodaysPrintDetail.aspx? $\mathrm{ID}=164487 \& \mathrm{Cat}=5 \& \mathrm{dt}=2 / 25 /$ $\underline{2009}$

Saif, M. S., Haq, M., \& Memon, K. S. (2005). Heavy metals contamination through industrial effluent to irrigation water and soil in Korangi area of Karachi (Pakistan). International Journal of Agriculture \& Biology, 7(4), 646-648. http://www.fspublishers.org/published_papers/88010_..pdf

Sial, R. A., Chaudhary, M. F., Abbas, S. T., Latif, M. I., \& Khan, A. G. (2006). Quality of effluents from Hattar industrial estate. Journal of Zhejiang University SCIENCE B, 7(12), 974-980. https://link.springer.com/article/10.1631/jzus.2006.B0974

Statistics on Textile Industry in Pakistan. (2013, March 18). The Express Tribune. http://tribune.com.pk/story/522292/statistics-on-textile-industry-in-pakistan/

SUPARCO. (2006). Study of widespread winter fog in Northeastern Pakistan and Northern India. (2006). Pakistan Space and Upper Atmosphere Research Commission 
(SUPARCO).

http://suparco.gov.pk/webroot/downloadables/space-research-

report(04-05).pdf

UNDP. (2010). Forests \& biodiversity - Information/Data Report (Pakistan, 2010), http://www.pk.undp.org/content/dam/pakistan/docs/Environment\%20\&\%20Climate \%20Change/UNDP-PK-ECC-Forests\%20and\%20Biodiversity.pdf

Water Pollution Factsheet. (2010). WWF-Pakistan, http://www.wwfpak.org/factsheets_wps.php

WWF. (2005). Floods linked to deforestation: WWF appeals to stop deforestation and increase in forest cover (Pakistan, 2005). http://www.illegal-logging.info/content/floodslinked-deforestation-wwf-appeals-stop-deforestation-and-increase-forest-cover

WWF. (2014). Situation analysis of the water resources of Lahore: Establishing a case for water stewardship, (Pakistan, 2014). http://www.wwfpak.org/wsp/pdf/SAWRLSummary.pdf

Zia, M. A., Khalil-ur-Rehman, F. A., \& Latif, R. (2005). Microbiological and chemical aspects of drinking water and treatment to enhance its quality. Journal of Research (Science), 16(1), 11-18. https://bzu.edu.pk/jrscience/vol16no1/2.pdf 